\title{
The More that Changes, the More that Stays the Same
}

\author{
Phil Hamilton* \\ Department of Agriculture, Cameron University, United States of America
}

*Corresponding author: Phil Hamilton, Department of Agriculture, Cameron University, United States of America.
Received Date: March 22, 2021

Published Date: March 31, 2021

\section{Opinion}

For nearly all residents of the United States (U.S.) and much of the world, it is easy to see that our country is deeply divided politically, economically, geographically, and philosophically. Recently, I was asked when I believed this division started. The expected responses were when Trump was elected President, when the Supreme Court became liberal for the first time, when Roe v. Wade was ruled by the Supreme Court, when Newt Gingrich, Speaker of the House, declared war on bipartisan participation, etc.

My answer was " 1776 ", recalling the biographies of the founding fathers found in Howard Zinn's A Peoples History of the United States. In our high school and college history textbooks we are told about the high risks that the founding fathers took, along with great sacrifices that they made in order to revolt from Britain to become a new country. What is left out is that it was the poor "commoner" who did most of the fighting. That is, most of the deaths in the Revolutionary War were of men who did not own much, if any, property [1].

However, the African slavery in the United States started in 1619 and in North America in the 1500's. But, in 1492 Christopher Columbus discovered the North American island of Hispaniola (present day Dominican Republic and Haiti) and wiped the entire indigenous population off the map with germ warfare called "mumps". From that day, under the justifications of "manifest destiny" and various other excuses, U.S. citizens have removed indigenous peoples (known as "Indians") from their lands and resettled them to less desirable locations. In early years, the nations (tribes) were restricted to living on the reservations assigned to them and forced to change their lifestyle from hunting to farming. For "civilized tribes" in the southeastern U.S., they were sometimes sent on a "Trail of Tears" march to present day Oklahoma to re-settle.

Ignoring the plight of the Indians for the moment, the Civil War was about slavery. The division was between the northern states and the southern states. It was not over "states' rights" as many southerners claim; neither was it a war of "northern aggression." The war was over slavery. But, when Confederate General Lee surrendered, not all was slavery and discrimination issues were solved. At that time, Republicans were the liberal party and Democrats were the conservative, "keep things as they were as close as possible" party. This was the advent of the "Jim Crow Laws" (the separate but equal fallacy) [2].

But, to those who like to study history that was in the past - not now. Certainly, one would think that with whole house refrigeration and heating, cars that will drive themselves, a digitized world with news and gossip at the fingertips, our nation and world is more civilized than the barbaric times of the past. But are they?

Gerrymandering and voter suppression laws are running rampant in certain states. Some of the states were not even part of the practicing Jim Crow group. Fascist and white supremacist groups are being lauded for their violence. According to The Cook Political Report, 81 million voters broke a voter count record by selecting the current President of the United States, there were still 74 million who voted for a President who can no longer serve on a charitable trust in New York due to mishandling of funds and impeached twice. The $51 \%$ to $47 \%$ split is very close. 
Over 2000 years ago a great leader and philosopher stated that the poor will be with us always. Looking at how the rich suppressed the poor in times past and in current times, that prophecy seems to have been fulfilled. Even though our richest billionaires are selfmade, many of the upper $1 \%$ of the wealthiest U.S. individuals inherited their money.

I am not a proponent of eliminating all billionaires from the U.S. If we did, all the billionaires would be in foreign countries (including some of ours). However, I do believe that there are certain rights that the poorest of poor deserve. Inadequate housing, food insecurity, and little or no health care are all travesties of the richest nation in the world. Many argue that these people made those choices. But nobody is as blind as one who refuses to see. Many did not inherit farmland won by land runs or homesteading or some other "silver spoon" inheritance. And the cycle keeps repeating itself [3].

How does this fit into agriculture? Farmers living in low density regions of farm states often have diverse political opinions and beliefs. My own experiences have included farmers demanding for the government to stay out of their business while they stood in line waiting for a crop subsidy check. Once I helped a farmer analyze how to let a poor farm pay for itself by setting aside all cropland on it and using his better land to grow his crops. In other words, this was a capitalistic approach to business. Just as tea merchants dressed as Indians and attacked the ship in harbor at the Boston Tea Party.

\section{Acknowledgement}

None.

\section{Conflict of Interest}

No conflict of interest.

\section{References}

1. Zinn, Howard (2015) A People's History of the United States. (Perennial Modern Classics Edition), HarperCollins Publishers, 195 Broadway, New York, NY 10007.

2. Wasserman, David, Sophie Andrews, Leo Saenger, Lev Cohen, et al (2020) 2020 National Popular Vote Tracker. https://cookpolitical. com/2020-national-popular-vote-tracker retrieved 3/19/2021.

3. Matthew. The Gospel According to Matthew, Ancient Scrolls 26:11 (0070). 